\title{
Potensi Keterdedahan Risiko Syariah Syarikat Pengendali Takaful Terpilih Di Malaysia
}

\author{
Mohd Faiz Mohamed Yusof, a,b* Joni Tamkin Borhan, ${ }^{a}$ Nurhanani Romli, ${ }^{a}$ \\ a Jabatan Syariah dan Ekonomi, Akademi Pengajian Islam, Universiti Malaya, Kuala Lumpur \\ ${ }^{b}$ Akademi Pengajian Islam Kontemporari, Universiti Teknologi MARA (UITM), Shah Alam \\ *Corresponding author: mrfaizyusof@gmail.com
}

\section{Article history}

Received: 2015-12-20

Received in revised form: 2016-01-05

Accepted: 2016-01-05

\begin{abstract}
Nowadays, various Islamic financial products have been developed and have grown tremendously in the financial markets, including Islamic equity, Islamic banking and takaful. The Islamic finance industry has its own uniqueness compared to the conventional financial industry due to the Islamic finance industry has a need for Shariah compliance in Islamic finance industry as known as Shariah risk. Globally, Islamic capital market was faced incident of Shariah risk in the end 2007 when Sheikh Taqi Uthmani has declared that $85 \%$ of sukuk issuance in the market are non Shariah compliant in the end of 2007 and cause a decrease of sukuk issuance in the following years in 2008. There are also dispute cases in Islamic banking in Malaysia such as issue of contract Bay 'Bithaman Ajil (BBA) is not shariah compliant. The takaful industry in Malaysia is also exposed to Shariah risks due to the shariah compliance requirements in all operations and activities of the takaful operator. Therefore, this study will describe the key elements that results shariah risk in Islamic finance. The research will identified potential of shariah risk using a qualitative methodology based on research data from five informants who were experienced shariah compliance management in takaful operator. This study will analyze qualitative data using a computerized program Altas.ti 7. The study infers that there are potential of Shariah risk and incident of Shariah risk in activities and operation of selected takaful operator in Malaysia.
\end{abstract}

Keywords: Shariah Risk, Element of Shariah risk, Potentials of Shariah Risk, Incidents of Shariah Risk, Takaful Operator

\begin{abstract}
Abstrak
Pada masa kini, pelbagai produk kewangan Islam telah dibangunkan dan telah berkembang pesat dalam pasaran kewangan termasuklah dalam ekuiti, perbankan, dan takaful. Industri kewangan Islam mempunyai keunikkan tersendiri berbanding industri kewangan konvensional. Keadaan ini adalah berikutan industri kewangan Islam mempunyai keperluan terhadap pematuhan syariah sekaligus mendedahkan industri kewangan Islam terhadap risiko yang dikenali sebagai risiko syariah. Industri pasaran modal Islam di peringkat global contohnya telah berhadapan dengan risiko syariah apabila pada penghujung tahun 2007 apabila Sheikh Taqi Uthmani telah mengistiharkan bahawa $85 \%$ sukuk yang berada di pasaran adalah tidak patuh syariah sekaligus menyebabkan penurunan terbitan sukuk pada tahun berikutnya. Dalam perbankan Islam di Malaysia pula terdapat pertikaian mengenai status patuh syariah kontrak Bay' Bithaman Ajil (BBA) sehingga terdapat kes-kes pertikaian yang dibawa ke mahkamah. Industri takaful di Malaysia turut terdedah kepada risiko syariah disebabkan keperluan pematuhan syariah dalam setiap operasi dan aktiviti Syarikat Pengendali Takaful (SPT). Justeru, kajian ini akan menjelaskan elemen-elemen utama yang menyebabkan risiko syariah dalam kewangan Islam. Kajian ini turut mengenalpasti potensi keterdedahan risiko syariah secara speksifik dalam SPT dengan menggunakan metodologi kualitatif berdasarkan data kajian daripada lima informan yang berpengalaman secara langsung dalam pematuhan syariah industri takaful. Kajian ini akan menganalisis data kualitatif menggunakan program berkomputer Altas.ti 7. Dapatan kajian menunjukkan terdapat pelbagai potensi risiko syariah dan insiden risiko syariah yang pelbagai dalam SPT.
\end{abstract}

Kata kunci: Risiko Syariah, Elemen Risiko Syariah, Potensi Risiko Syariah, Syarikat Pengendali Takaful 


\subsection{PENDAHULUAN}

Industri takaful merupakan industri yang penting terhadap pembangunan ekonomi di Malaysia. Perkembangan industri takaful juga selaras dengan objektif menjadikan Malaysia sebagai sebuah pusat kewangan Islam antarabangsa. Ini dijelaskan oleh Gabenor Bank Negara Malaysia yang menyatakan bahawa objektif industri takaful untuk mewujudkan syarikat pengendali takaful (SPT) yang bertaraf antarabangsa dan mengetuai industri takaful di peringkat global. Takaful merupakan produk pengganti insurans konvensional khususnya bagi masyarakat Muslim apabila produk insurans konvensional telah difatwakan haram oleh Jawatankuasa Fatwa Kebangsaan (1984). Produk takaful merupakan produk patuh syariah yang bebas daripada sebarang elemen atau transaksi yang bercanggah dengan syarak. Ini bererti keperluan terhadap pematuhan syariah dalam produk takaful menyebabkan SPT terdedah kepada potensi risiko syariah. Pengurusan risiko syariah merupakan proses yang berterusan. SPT perlu memastikan kepatuhan syariah secara keseluruhan dalam operasi SPT. Sebarang elemen atau aktiviti tidak patuh syariah akan menyebabkan kerugian yang besar bukan sahaja kepada para peserta, malahan kepada pemegang saham, pihak pengurusan SPT dan imej industri kewangan Islam secara keseluruhannya (Nooraslinda, et. al., 2012). Di Malaysia, sehingga kini terdapat 11 SPT yang mempunyai lesen pengendali takaful sama ada lesen komposit iaitu takaful am dan keluarga atau lesen pengendali takaful keluarga sahaja. Namun begitu, kajian ini hanya memilih lima SPT yang dipilih secara rawak daripada 11 SPT yang beroperasi di Malaysia.

\subsection{METODOLOGI}

Kajian ini mengaplikasikan pendekatan kualitatif. Metode kualitatif digunakan dalam kajian ini bagi merangka teoritikal risiko syariah dan mengenalpasti potensi risiko syariah dalam operasi sebenar SPT terpilih di Malaysia. Ini kerana pendekatan kualitatif merupakan metode yang bertujuan memahami sesuatu permasalahan, fenomena atau situasi secara mendalam bagi menghasilkan penyelesaian mengenai permasalahan kajian tersebut (Denzin \& Lincoln 2005; Guba \& Lincoln 1994; Bailey 2007). Kajian ini mengumpulkan data secara kualitatif dengan menemubual sebanyak lima orang informan yang mewakili lima SPT di Malaysia. Informan dipilih secara rawak berdasarkan penerimaan dan kesudian informan untuk proses temubual bagi kajian ini. Informaninforman merupakan Pegawai Syariah yang bertanggungjawab menguruskan pematuhan syariah dalam keseluruhan operasi dan aktiviti SPT. Pegawai Syariah SPT dipilih sebagai informan dalam kajian ini berikutan Pegawai Syariah SPT mempunyai dua tugas dan peranan utama. Pertama, peranan Pegawai Syariah untuk memastikan pematuhan syariah termasuklah menyusun atur pandangan dan resolusi syariah Jawatankuasa Syariah SPT dalam operasi SPT. Kedua, Pegawai Syariah turut berperanan memastikan operasi SPT berurusniaga secara baik dan teratur bagi memastikan kestabilan dan pembangunan urusniaga SPT (Rusni Hasan et al. 2013). Dengan kata lain, Pegawai Syariah mempunyai tanggungjawab untuk mengharmonikan keperluan operasi sebenar dalaman SPT dengan keperluan pematuhan syariah yang ditetapkan oleh Jawatankuasa Syariah SPT sendiri dan pihak pengawalselia daripada Majlis Penasihat Syariah BNM. Oleh yang demikian, Pegawai Syariah merupakan informan yang paling sesuai untuk memahami potensi keterdedahan risiko syariah dalam situasi sebenar operasi dan aktiviti. Tambahan lagi, kesemua Pegawai Syariah SPT yang telah ditemubual mempunyai pengalaman paling minima selama 2 tahun dalam industri kewangan Islam serta mempunyai latar belakang pengajian minima ijazah sarjana muda dalam bidang fiqh dan usul fiqh, perbankan dan kewangan Islam atau bidang perundangan Islam dan sivil. Selanjutnya, hasil data kajian ini melalui proses pengekodan untuk mengenalpasti potensi keterdedahan risiko syariah dalam SPT terpilih tersebut. Kajian ini menggunakan program analisis 
kualitatif berkomputer iaitu Altas.ti 7 bagi memudahkan proses menganalisis data secara induktif dan deduktif dalam kajian ini (Saldana, 2013).

\subsection{KONSEP RISIKO SYARIAH}

Daripada aspek penggunaan istilah, terdapat istilah berbeza yang digunakan dalam menjelaskan risiko berkaitan pematuhan syariah contohnya 'risiko syariah' (Ginena, 2014), 'risiko ketidakpatuhan syariah' (Lahsasna, 2014), 'risiko pematuhan syariah' (DeLorenzo, 2007), 'risiko operasi' (Haron \& Taylor, 2009) dan lain-lain. Walau bagaimanapun, kajian ini akan menyelaraskan penggunaan istilah kepada istilah 'risiko syariah' sahaja. Terdapat istilah-istilah yang perlu difahami berkaitan risiko syariah. Pertama, 'potensi' risiko syariah bermaksud isu syariah dalam operasi SPT yang belum diputuskan oleh Jawatankuasa Syariah SPT disebabkan memerlukan kajian dan pertimbangan yang selanjutnya. Potensi risiko syariah ini perlu dilaporkan kepada BNM. Kedua, 'insiden' risiko syariah ialah apa sahaja aktiviti tidak patuh syariah yang benar-benar telah berlaku dalam institusi kewangan Islam. Insiden risiko syariah ini telah dipersetujui oleh Jawatankuasa Syariah SPT sebagai tidak patuh syariah. Insiden risiko syariah seperti ini juga perlu dilaporkan oleh BNM (Lahsasna, 2014). Walau bagaimanapun, kajian ini mengumpulkan data kualitatif temubual berdasarkan pengetahuan dan pengalaman informan yang bertanggungjawab dalam pematuhan syariah SPT. Kebanyakkan isu syariah telah diputuskan oleh Jawatankuasa Syariah SPT masing-masing sama ada wujud potensi atau insiden risiko syariah yang sebenar. Oleh yang demikian, kajian ini mengandaikan data-data yang dinyatakan oleh informan sebagai potensi keterdedahan risiko syariah tanpa terikat dengan definisi potensi risiko syariah dan insiden risiko syariah yang perlu dilaporkan secara rasmi kepada BNM.

Dari segi definisi risiko syariah, DeLorenzo (2007) mendefinisikan risiko syariah sebagai kebarangkalian produk atau perkhidmatan kewangan tidak mematuhi atau akan tidak mematuhi untuk tempoh masa hadapan terhadap perundangan Syariah yang telah jelas. Manakala, Acher dan Haron (2007) pula mendefinisikan risiko syariah sebagai risiko ketidakpatuhan syariah disebabkan oleh sistem dalaman institusi kewangan Islam dan juga kakitangan yang terlibat dalam operasi dan urusniaga kewangan Islam. Ibn Dawiyan (1972) pula mengulas pengertian risiko syariah bermaksud ketidakpastian mengenai suatu perkara akan menyebabkan berlaku pertikaian dan mendedahkan kepada risiko ketidakpatuhan syariah. Begitu juga Bälz (2008) yang mendefinisikan risiko syariah sebagai kebarangkalian transaksi kewangan Islam dipertikaikan sebagai tidak patuh syariah. Islamic Financial Services Board (IFSB) menggunakan istilah 'risiko ketidakpatuhan Syariah'. Berdasarkan beberapa pendefinisian ini, risiko syariah boleh difahami sebagai risiko berlaku aktiviti tidak patuh syariah dalam apa-apa operasi institusi kewangan Islam. Potensi keterdedahan risiko syariah pula boleh difahami sebagai apa sahaja kebarangkalian atau kemungkinan atau ruang-ruang yang boleh berlaku apa-apa aktiviti tidak patuh syariah dalam industri kewangan Islam.

Risiko syariah adalah sebahagian daripada risiko operasi yang perlu menjalani proses mengenalpastikan keterdedahan terhadap ketidakpatuhan syariah yang diikuti tindakan untuk mengawal daripada berlaku insiden ketidakpatuhan syariah tersebut. Secara umumnya, terdapat keterdedahan kepada insiden risiko syariah dalam industri takaful. Contohnya, produk pelan takaful keluarga berkaitan pelaburan memerlukan pemilihan portfolio pelaburan daripada SPT. SPT telah secara senjaga atau tidak telah memilih portfolio yang sedia maklum tidak patuh syariah untuk melaburkan dana pelaburan peserta tersebut. Situasi ini menyebabkan berlaku insiden tidak patuh syariah dalam operasi SPT tersebut. Kejadian insiden tidak patuh syariah ini menyebabkan terdapat pendapatan tidak diiktiraf syariah dalam keuntungan SPT (Frenz \& Soualhi, 2010). Oleh sebab itu, SPT perlu mengasingkan pendapatan tidak diiktiraf syariah tersebut dan kemudiannya dilupuskan 
melalui pemberian kepada badan-badan kebajikan (Asyraf Wajdi Dusuki, Mohammad Mahbubi Ali \& Lokmanulhakim Hussain 2012) atau sebagaimana yang dipersetujui oleh Jawatankuasa Syariah SPT masing-masing.

\subsection{ELEMEN-ELEMEN UTAMA RISIKO SYARIAH}

Terdapat unsur-unsur utama yang menyebabkan risiko syariah dalam kewangan Islam termasuklah kontrak takaful. Antara unsur-unsur utama yang menyebabkan risiko syariah dalam kewangan Islam ialah riba, gharar, maisir, ghubn, ikrah, taghrir dan ghalat.

Rajah 1: Elemen-Elemen Utama dalam Risiko Syariah

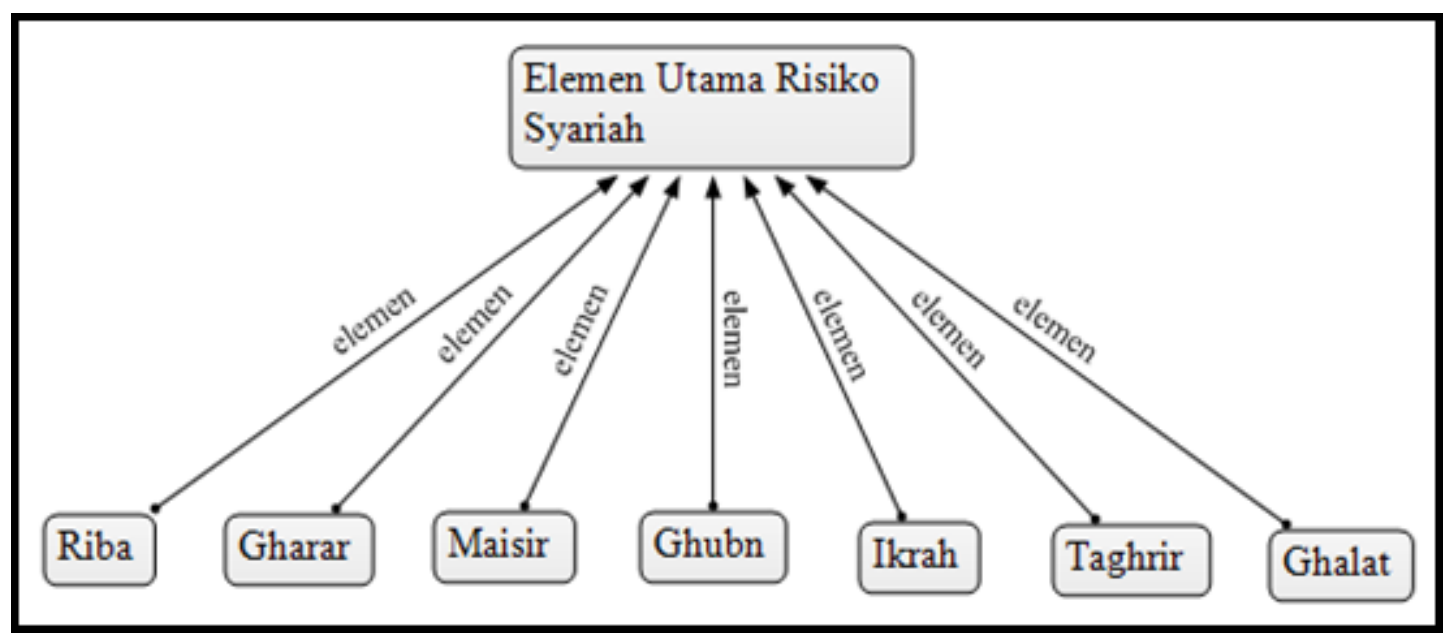

\subsection{RIBA}

Riba merupakan elemen yang dilarang secara jelas dalam Al-Quran, antaranya surah Ali 'Imran 3: 130 dan surah al-Baqarah 2: 275. Larangan terhadap elemen riba turut dijelaskan melalui hadis riwayat Muslim (1981) bermaksud daripada Jabir r.a yang bermaksud, "Bahawa Rasulullah SAW melaknat pengambil dan pemberi riba, penulis yang mencatat transaksi riba dan saksi kedua-duanya dan Rasulullah SAW mengatakan mereka semua adalah sama." Riba dalam transaksi kewangan masa kini difahami sebagai sejumlah wang bayaran tambahan yang dikenakan ke atas peminjam yang mesti dibayar kepada pemiutang sebagai pulangan terhadap pinjaman yang telah diberikan berdasarkan tempoh masa bayaran dibuat. Dalam kontrak takaful, elemen riba tidak berlaku secara langsung kerana kontrak takaful yang berasaskan kerjasama dan tolong-menolong. Menurut Mohd Ma'sum Billah (2003), asas kontrak takaful bertentangan dengan asas kontrak insurans konvensional contohnya apabila syarikat insurans membayar kepada orang yang dilindungi insurans lebih daripada duit yang dibayar oleh pemegang polisi insurans merupakan riba al-fadhl. Riba al-fadhl bermaksud melebihkan, iaitu berlaku pertambahan pada salah satu tukaran bagi jual beli barangan ribawi (Muhammad Solah al-Sowi, 1990). Begitu juga, bayaran manfaat yang dibayar oleh syarikat insurans kepada orang yang dilindungi ditangguhkan untuk suatu tempoh yang akan datang dikategorikan sebagai riba al-nasi'ah (Mohd Ma'sum Billah, 2003). Muhammad Solah al-Sowi (1990) juga menjelaskan riba nasi'ah yang bermaksud jual beli bertangguh iaitu barangan atau perkhidmatan diperolehi tidak secara tunai. Kedua-dua unsur riba dalam insurans konvensional ini yang menyebabkan insurans konvensional dianggap tidak patuh syariah berdasarkan fatwa Muzakarah Jawatankuasa Fatwa Kebangsaan (1984) Bagi Hal Ehwal Agama Islam. Walau bagaimanapun, 
elemen riba masih lagi boleh berlaku dalam kontrak takaful misalnya kegagalan pihak SPT memastikan pemilihan kaunter pelaburan yang bebas daripada transaksi riba. Kaunter pelaburan yang melibatkan transaksi riba contohnya pelaburan yang melibatkan perbankan konvensional yang memberi pinjaman berasaskan riba.

\subsection{GHARAR}

Dari sudut syariah dalam kewangan Islam, gharar merupakan unsur yang dilarang yang menyebabkan tidak patuh syariah. Ini kerana gharar adalah unsur-unsur ketidakpastian atau keraguan yang boleh menyebabkan pertikaian antara pihak-pihak yang berkontrak. Larangan terhadap elemen gharar dalam transaksi urusniaga berdasarkan dalil al-Quran surah al-Nisa' 4: 29 dan surah al-Mutaffifin 83: 1-3. Begitu juga terdapat dalil daripada hadis menjelaskan larangan terhadap elemen gharar antara hadis riwayat Muslim (1955: 1153) bermaksud "Rasulullah s.a.w melarang jual beli al-hasat (yang ditentukan melalui balingan batu) dan jual beli gharar." Gharar merupakan salah satu unsur yang menyebabkan insurans konvensional difatwakan haram oleh Majlis Fatwa Kebangsaan (1984). Ini berikutan tiada kepastian mengenai bila pemegang polisi insurans akan dapat menggunakan manfaat insurans konvensional yang telah dibelinya. Sekiranya para pemegang polisi insurans tidak mengalami sebarang musibah, bagaimanakah mengenai situasi wang caruman pemegang polisi insurans tersebut. Adakah wang tersebut menjadi milik pemegang polisi insurans atau menjadi milik syarikat insurans tersebut (Ahmad Hidayat Buang, 2000). Walaupun kontrak takaful secara umumnya adalah jelas dan nyata serba bebas daripada sebarang unsur gharar. Namun begitu, terdapat kemungkinan-kemungkinan wujud gharar dalam kontrak takaful misalnya sekiranya agen syarikat takaful gagal menyatakan dengan jelas jumlah perlindungan keseluruhan pelindungan takaful serta jumlah manfaat takaful yang berkaitan ataupun sekiranya agen tersebut gagal menyatakan dengan jelas berapakah jumlah caruman yang perlu dibayar oleh bakal peserta takaful sebelum menyertai kontrak.

\subsection{MAISIR}

Maisir atau judi bermaksud apa sahaja aktiviti yang melibatkan pertaruhan. Pihak yang memenangi pertaruhan akan memperolehi semua nilai pertaruhan manakala pihak yang kalah akan hilang pertaruhannya. Judi merupakan elemen yang jelas mempunyai larangan berdasarkan Al-Quran melalui Surah al-Maidah 5: 90 dan Surah al-Baqarah 2: 219. Dalil daripada ayat-ayat Al-Quran ini jelas menunjukkan bahawa judi merupakan elemen yang dilarang dalam kehidupan masyarakat Muslim termasuklah dalam transaksi kewangan Islam. Unsur perjudian merupakan salah satu sebab insurans konvensional difatwakan haram oleh Majlis Fatwa Kebangsaan (1984). Ini kerana terdapat unsur judi yang mana para pemegang polisi insurans konvensional berharap akan memperolehi jumlah keuntungan yang besar manfaat insurans setelah membayar sejumlah kecil wang untuk mendapatkan polisi insurans tersebut (Mohd Ma'sum Billah, 2003). Ini seperti aktiviti pertaruhan dalam judi yang mana pihak yang berjudi akan menpertaruhkan sejumlah kecil wang atau barangan pertaruhan dengan tujuan untuk mendapatkan lebih banyak keuntungan (Muslehuddin, 1979). Kontrak takaful bebas daripada transaksi perjudian kerana takaful berasaskan kerjasama dan semangat tolong-menolong di kalangan para peserta takaful serta bukan atas tujuan membayar sedikit wang caruman sebagai pertaruhan untuk mendapatkan jumlah wang manfaat insurans yang bergandaganda lebih besar jumlahnya.

\subsection{TAGHRIR}

Taghrir merupakan salah satu daripada unsur-unsur yang menyebabkan risiko syariah dalam kewangan Islam. Taghrir merupakan aktiviti apabila satu salah pihak mempengaruhi pihak yang lain 
dengan fakta atau maklumat yang tidak benar bertujuan agar pihak tersebut bersetuju untuk terlibat dalam kontrak tersebut sama ada jual beli, pinjaman, gadaian, takaful dan lain-lain (Al-Kafif, 1996). Taghrir dalam perbuatan pula ialah tindakan dalam bentuk perbuatan terhadap barang jualan dengan menunjukkan keadaan yang sebaliknya dengan keadaan sebenar barang jualan. Contohnya, pihak A menjual kasut terpakai tetapi membungkuskan semula kasut tersebut agar kelihatan seperti baru untuk dijual kepada pihak B. Taghrir seperti ini adalah dilarang oleh syariah yang turut dikategorikan sebagai gharar oleh Ibn Rushd (1995). Dalam praktis transaksi kewangan semasa, terdapat aktiviti taghrir yang berlaku contohnya produk dan perkhidmatan telah salah fakta semasa dibentangkan kepada pelanggan atau bakal pelanggan sama ada dalam perkataan ataupun bentuk tindakan. Keputusan untuk melaksanakan kontrak tersebut adalah berdasarkan pembentangan produk dan perkhimatan yang silap tadi. Sekiranya pihak berkontrak telah mengetahui bahawa dia telah ditipu semasa pembentangan produk dan perkhidmatan kewangan. Maka, pihak tersebut boleh mengambil tindakan perundangan termasuklah membatalkan kontrak atau membawa kes tersebut kepada mahkamah.

\subsection{GHALAT}

Ghalat atau kesilapan ialah salah tanggapan mengenai sesuatu perkara. Dengan erti kata yang lain, sesuatu anggapan yang berbeza dengan realiti tanpa disedari oleh pihak berkontrak. Contoh ghalat dalam kontrak jual beli ialah ghalat berlaku apabila tanggapan pihak pembeli tidak berlaku sepertimana yang dikehendaki oleh pembeli tersebut. Ini kerana pihak pembeli telah membeli barangan tersebut disebabkan tanggapannya yang tertentu terhadap barangan itu (al-Zarqa 1996). Ghalat boleh dibahagikan kepada dua iaitu ghalat 'aqid dan ghalat wadhih. Contoh ghalat 'aqid atau ghalat tidak nyata (Hussin Salamon, 2009) dalam kontrak takaful misalnya seorang peserta takaful menyertai kontrak takaful berkaitan pelaburan dengan anggapan bahawa harga-harga unit saham takaful berkaitan pelaburan akan meningkat dan memberi pulangan yang baik. Walau bagaimanapun, harga unit saham takaful berkaitan pelaburan tersebut menurun setelah peserta tersebut menyertai kontrak takaful. Situasi ini merupakan ghalat 'aqid dan akad ini tidak mempunyai unsur gharar dan situasi turun naik harga unit takaful berkaitan pelaburan merupakan perkara normal yang berlaku dalam pelaburan unit-unit saham produk takaful berkaitan pelaburan. Ghalat wadhih pula ialah kesilapan yang berlaku secara jelas dan nyata. Kesilapan yang nyata ini boleh berlaku dalam dua keadaan sama ada secara jelas berlainan dengan kehendak pihak berkontrak sepertimana telah dipersetujui atau berdasarkan bukti-bukti tertentu yang menunjukkan kesalahan pihak penjual dan bukannya pembeli (al-Zarqa, 1996).

Ghalat dalam kontrak takaful boleh berlaku contohnya seseorang menyertai kontrak takaful berkaitan pelaburan sebanyak RM100 sebulan dengan anggapan bahawa beliau boleh mendapat manfaat kemasukkan hospital tanpa bayaran tunai sekiranya berlaku musibah kemalangan atau sakit. Akan tetapi, hakikatnya produk takaful berkaitan pelaburan yang disertainya tidak mempunyai manfaat tambahan kemasukkan hospital tanpa bayaran tunai. Dalam keadaan ini terdapat unsur ghalat atau kesilapan dalam anggapan peserta tersebut semasa menyertai takaful dan tidak mengetahui realitinya bahawa manfaat kemasukkan hospital tanpa bayaran tunai tiada dalam produk takaful berkaitan pelaburan yang disertainya. Kebiasaan kontrak takaful memberi pilihan atau khiyar kepada para peserta selama 15 hari atau sepertimana dalam kontrak takaful sama ada untuk membatalkan atau meneruskan kontrak takaful setelah sijil polisi takaful diterima oleh peserta takaful. 


\subsection{IKRAH}

Ahmad Ibrahim Biq (1936) menjelaskan ikrah atau paksaan bermaksud memaksa seseorang untuk melakukan perkara yang tidak dikehendakinya. Akan tetapi, untuk mengelakkan terjadinya kemudaratan lebih buruk. Pihak tersebut tetap melakukan perkara tersebut walaupun dalam keadaan terpaksa dan buakan kehendak sebenarnya pihak yang berkontrak. Contoh paksaan dalam jual beli misalnya apabila seseorang bertanya mengenai harga dan speksifikasi barang jualan. Penjual tersebut terus mendesak dan memaksa individu tersebut untuk membeli barangan tersebut serta mengancam dengan perkataan dan perbuatan bahawa individu tersebut tidak dibenar meninggalkan premis jualan jika tidak membeli barangan tersebut. Akhirnya, individu membeli barangan tersebut secara terpaksa bagi mengelak kemudaratan yang lebih besar.

\subsection{GHUBN}

Ghubn turut merupakan salah satu daripada unsur-unsur risiko syariah dalam kewangan Islam. Ghubn dalam kewangan Islam berlaku apabila berlaku ketidakadilan dalam harga dan subjek transaksi sama ada pengurangan atau penambahan dalam harga dan subjek transaksi. Perbezaan harga dan subjek transaksi ini tidak diketahui oleh salah satu pihak berkontrak semasa kontrak transaksi dipersetujui (Al-Khafif, 1996). Ini bererti ghubn merupakan kesalahan apabila dilakukan oleh salah satu pihak yang berkontrak secara sengaja. Namun begitu, sekiranya pengurangan harga atau subjek transaksi sama ada barangan atau perkhidmatan disebabkan proses permintaan dan penawaran dalam pasaran, ghubn ini tidak dianggap sebagai satu kesalahan (Hussin Salamon, 2009).

Kelima-lima elemen seperti riba, gharar, maisir, ghubn, ikrah, taghrir dan ghalat merupakan elemen-elemen utama yang menyebabkan ketidakpatuhan syariah. Namun begitu, elemen ketidakpatuhan syariah tidak hanya terhad kepada elemen-elemen ini sahaja. Majlis Penasihat Syariah BNM boleh mengeluarkan garis panduan dan resolusi syariah dari masa ke semasa berkaitan elemen-elemen lain mengenai ketidakpatuhan syariah terutamanya elemen-elemen yang menyebabkan kemudaratan dan kezaliman sama ada kepada para peserta takaful mahupun pihak SPT. Ini kerana Majlis Penasihat Syariah merupakan pihak yang berkuasa berkaitan tadbir urus syariah melibatkan industri perbankan Islam dan takaful. Resolusi syariah Majlis Penasihat Syariah BNM diterima sebagai pandangan ijma' yang perlu dipatuhi oleh semua institusi kewangan Islam berdasarkan perundangan syariah dan diiktiraf melalui perundangan sivil melalui Akta Perkhidmatan Kewangan Islam 2013 (Mohd Faiz Mohamed Yusof et al., 2015).

\subsection{POTENSI KETERDEDAHAN RISIKO SYARIAH DALAM INDUSTRI KEWANGAN ISLAM}

Rajah 2 menunjukkan potensi-potensi yang menyebabkan terjadi insiden risiko syariah dalam kezangan Islam.

Rajah 2: Potensi Risiko Syariah dalam Kewangan Islam 


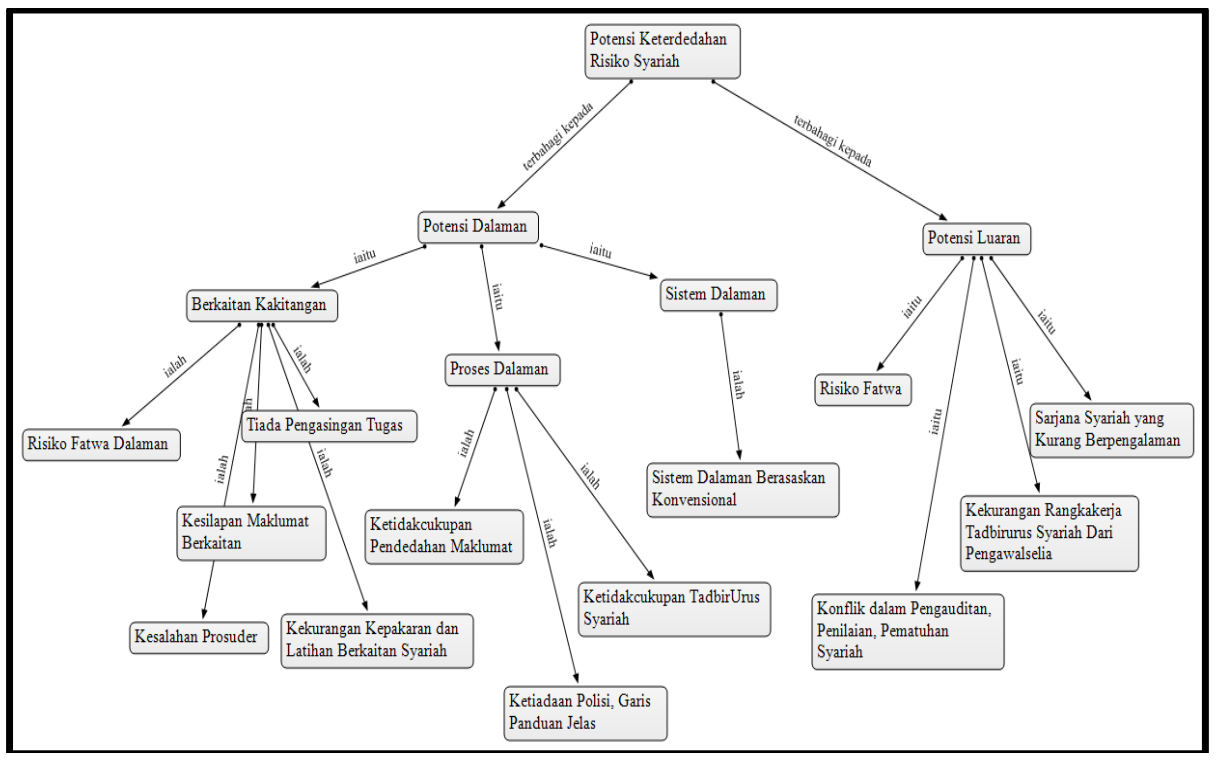

Diubahsuai daripada DeLorenzo (2007); Lahsasna (2014); Ginena (2014).

Potensi risiko syariah dalam industri kewangan Islam mempunyai rangka teoritikal dan praktis yang kritikal dan memerlukan penjelasan yang mendalam. Walau bagaimanapun, kajian ini hanya menjelaskan potensi risiko syariah secara umum sahaja tanpa menyatakan contoh-contoh terperinci dalam industri kewangan Islam. Potensi keterdedahan risiko syariah dalam industri kewangan Islam boleh dibahagikan kepada dua iaitu potensi dalaman dan potensi luaran.

\subsection{POTENSI DALAMAN}

Risiko syariah boleh berlaku disebabkan kegagalan institusi kewangan di peringkat dalaman untuk mematuhi aspek syariah melibatkan kakitangan berkaitan, proses dalaman, dan sistem. Pertama, yang melibatkan kakitangan institusi kewangan Islam itu sendiri iaitu risiko fatwa, kesilapan maklumat berkaitan, perlanggaran prosuder dan lain-lain. Risiko syariah dalam institusi kewangan Islam juga boleh berlaku disebabkan oleh risiko fatwa apabila berlaku kegagalan Jawatankuasa Syariah menguasai secara mendalam struktur operasi patuh syariah secara keseluruhannya. Kegagalan ini akan menyebabkan Jawatankuasa Syariah mungkin mengeluarkan fatwa yang tidak betul, tidak jelas atau terlalu sukar untuk dipraktikkan dalam pasaran sebenar kewangan Islam (DeLorenzo, 2007). Selain itu, kesilapan maklumat juga boleh menyebabkan berlaku risiko syariah. Kesilapan maklumat ini berlaku sekiranya manual pematuhan syariah tidak digunakan melalui sistem berkaitan untuk memudahkan penyaringan transaksi dalam kontrak kewangan Islam. Pelanggaran garis panduan prosedur dalam kelulusan produk, transaksi, dan dokumen perundangan juga akan menyebabkan risiko operasi sekiranya kelulusan tersebut melibatkan pematuhan syariah. Ini akan menyebabkan terjadi insiden risiko syariah. Dalam praktis sebenar, kelulusan produk, transaksi, dan dokumen perundangan mesti melibatkan pegawai perundangan sivil dan Jawatankuasa Syariah bagi memastikan setiap kelulusan produk, transaksi, dan dokumen perundangan berdasarkan pematuhan syariah serta kelulusan perundangan sivil (Ginena, 2014).

Seterusnya, kekurangan kakitangan berlatar belakang pengajian syariah dan ditambah lagi dengan ketiadaan latihan berkaitan pematuhan syariah akan menyebabkan berlaku insiden risiko syariah dalam operasi industri takaful. Kekurangan pengetahuan berkaitan syariah akan menyebabkan kakitangan bahagian syariah tidak dapat menjalankan tugas pengauditan, kajian semasa, dan penilaian semula dalam aspek syariah terhadap isu, produk, transaksi dan lain-lain operasi dalam institusi kewangan Islam. Potensi keterdedahan risiko turut disebabkan proses dalaman institusi kewangan itu sendiri. Terdapat beberapa masalah berkaitan proses dalaman contoh terdapat 
banyak perubahan dan perbezaan dalam polisi, prosedur, dan bidang tanggungjawab operasi institusi kewangan Islam menyebabkan ketiadaan standard yang jelas untuk diikuti oleh kakitangan atau pihak yang berkaitan sekaligus berpotensi menyebabkan terjadinya insiden risiko syariah. Seterusnya, potensi risiko syariah disebabkan kegagalan institusi kewangan Islam bagi menyediakan sistem tadbir urus syariah akan menyebabkan kelemahan dalam pengawalan pematuhan Syariah. Kekurangan dalam aspek tadbir urus syariah di peringkat dalaman institusi ini akan menyebabkan potensi keterdedahan risiko Syariah (Zulkifli Hasan, 2012). Potensi keterdedahan risiko syariah juga disebabkan oleh sistem teknologi maklumat dalam institusi kewangan Islam. Ini berikutan kebanyakkan sistem teknologi maklumat dalam institusi kewangan adalah berasaskan institusi kewangan konvensional. Oleh yang demikian, sistem tersebut mempunyai kelemahan dari aspek penyaringan terhadap elemen-elemen tidak patuh syariah sekaligus mendedahkan institusi kewangan Islam kepada insiden risiko syariah.

\subsection{POTENSI LUARAN}

Potensi luaran ialah perkara-perkara luaran daripada institusi kewangan Islam itu sendiri yang menyebabkan berlaku keterdedahan kepada risiko syariah. Risiko fatwa daripada luaran merupakan sebahagian daripada potensi luaran keterdedahan risiko syariah. DeLorenzo (2007) menjelaskan terdapat tiga sebab penolakkan terdapat fatwa daripada luaran. Pertama, perbezaan keputusan disebabkan perbezaan mazhab atau pengambilan mazhab yang minoriti. Kedua, kekurangan aspek ketelusan dan pendedahan keputusan fatwa secara terperinci kepada para pelabur dan Jawatankuasa Syariah dalaman. Ketiga, penolakkan fatwa daripada para pelanggan kerana para pelanggan berpendapat keputusan fatwa tidak mencukupi dalam mematuhi keperluan terhadap agama. Faktor luaran potensi risiko syariah juga disebabkan konflik dalam proses pengauditan syariah contohnya pihak pematuhan syariah dalaman institusi kewangan Islam terlibat secara langsung dalam pengauditan syariah daripada pihak luaran yang mungkin menyebabkan bias dan gagal mencapai matlamat dalam pengauditan syariah ini. Ini juga menyebabkan potensi untuk berlaku insiden risiko syariah disebabkan kegagalan semasa proses pengauditan syariah. Seterusnya, kekurangan kepakaran dan pengalaman pihak yang dilantik untuk mengawalselia pematuhan syariah juga berpotensi untuk mengakibatkan berlaku risiko syariah. Selain itu, potensi keterdedahan risiko syariah juga mungkin disebabkan oleh ketiadaan garis panduan atau rangka kerja daripada pihak pengawalselia seperti Bank Negara Malaysia khususnya dalam isu-isu syariah yang besar dalam pematuhan syariah. Potensi keterdedahan risiko syariah yang telah dinyatakan merupakan potensi risiko syariah secara umum yang mungkin berlaku dalam mana-mana industri kewangan Islam sama ada perbankan Islam, pasaran modal Islam mahupun takaful. Berikut merupakan hasil dapatan kajian potensi risiko syariah dalam SPT yang dikenalpasti melalui proses temubual Pegawai-Pegawai Syariah lima SPT terpilih di Malaysia.

\subsection{DAPATAN KAJIAN}

Hasil dapatan kajian daripada data temubual Pegawai Syariah SPT menunjukkan bahawa potensi keterdedahan risiko syariah dalam SPT boleh dikenalpasti melalui isu-isu syariah yang timbul dalam operasi SPT. Potensi keterdedahan risiko syariah melibatkan lima aspek dalam operasi SPT iaitu penerimaan risiko, sistem, operasi, tadbir urus, dan produk sepertimana rajah berikut:

Rajah 3: Potensi Keterdedahan Risiko Syariah dalam SPT 


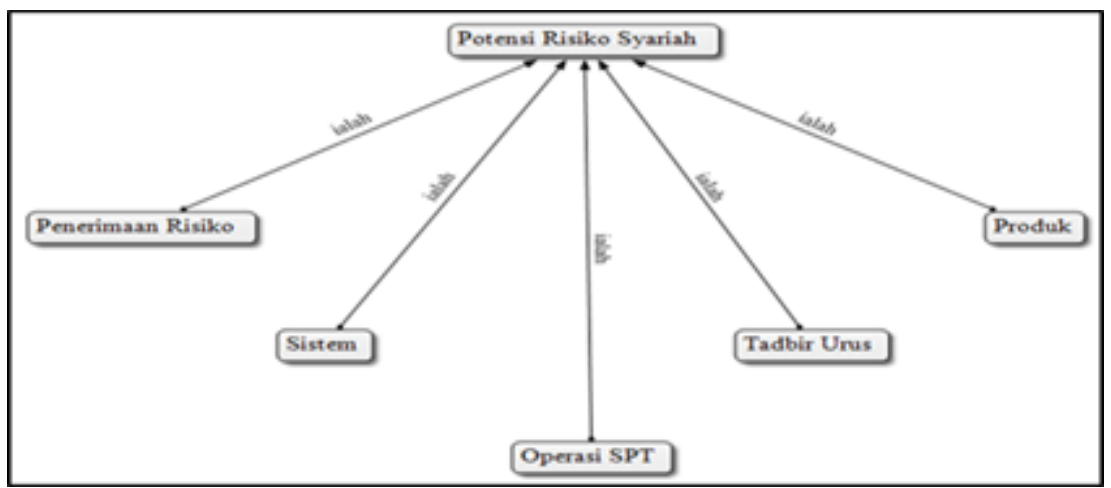

Pertama, potensi keterdedahan risiko syariah dalam SPT boleh berlaku dalam aspek penerimaan risiko dalam kontrak takaful am dan keluarga. Aspek penerimaan risiko dalam kontrak takaful merupakan antara ruang-ruang kelompangan yang boleh menyebabkan berlaku perkara tidak patuh syariah. Ini kerana penerimaan risiko dalam SPT berbeza jika dibandingkan dengan penerimaan risiko oleh syarikat insurans konvensional. Risiko yang diterima oleh SPT dalam kontrak takaful mesti mematuhi aspek syariah khususnya berkaitan perkara-perkara yang dilarang seperti melibatkan eleman riba, ketidakpastian (gharar) dan perjudian. Pegawai Syariah SPT A menyatakan bahawa tiada sebarang garis panduan yang ditetapkan oleh pengawalselia untuk menentukan status patuh syariah atau sebaliknya dalam aspek penerimaan risiko kontrak takaful. Malahan, aspek penerimaan risiko ini merupakan perkara yang sangat subjektif dan sukar untuk menentukan penanda aras mengenai penerimaan risiko dalam kontrak takaful. Pegawai Syariah SPT A menyatakan terdapat usaha daripada pengawalselia iaitu Bank Negara Malaysia untuk mengeluarkan parameter dalam penerimaan risiko tetapi masih tidak berhasil sehingga kini. Ini kerana parameter penerimaan risiko ini sangat subjektif dan melibatkan pelbagai perkara contohnya dalam majlis kebudayaan sukar menentukan jenis persembahan yang dibenarkan atau sebaliknya. Hasil temubual kelima-lima informan juga mendapati terdapat pelbagai potensi keterdedahan risiko syariah dalam SPT dalam penerimaan risiko kontrak takaful seperti yang ditunjukkan dalam rajah 4:

\section{Rajah 4: Potensi Keterdedahan Risiko Syariah dalam Penerimaan Risiko Kontrak Takaful}

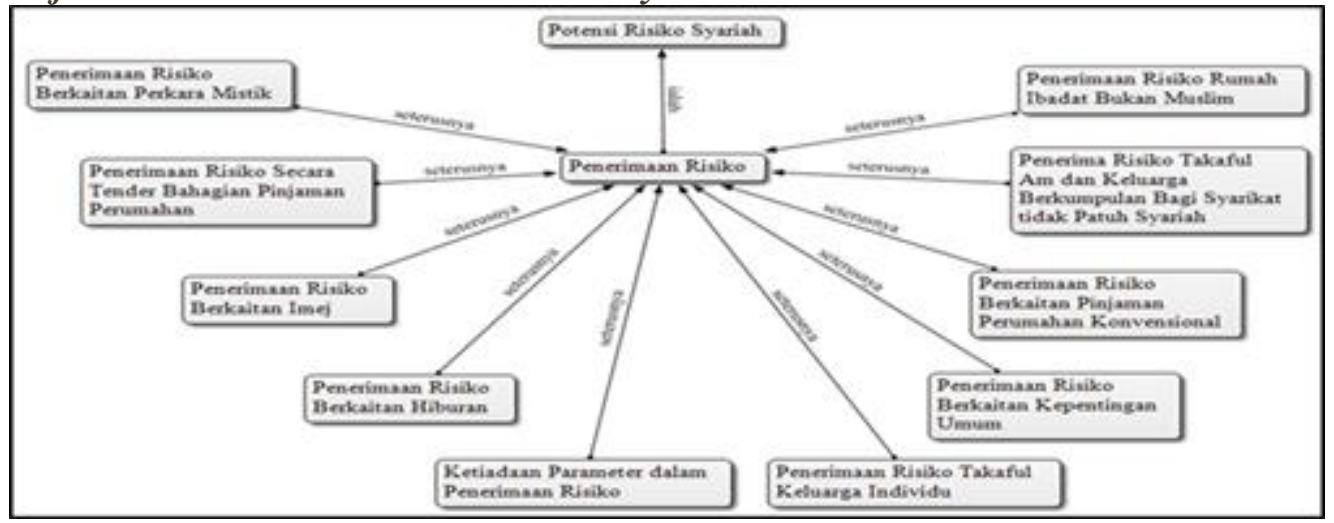

Rajah 4 juga menunjukkan pelbagai potensi keterdedahan risiko syariah yang melibatkan penerimaan risiko dalam kontrak takaful. Rajah 4 ini turut memberi gambaran bahawa aspek penerimaan risiko ini bersifat subjektif dan menyebabkan kesukaran dalam menentukan penanda aras patuh syariah atau sebaliknya. Oleh yang demikian, penentuan mengenai risiko yang boleh diterima atau tidak masih tertakluk kepada keputusan resolusi syariah Jawatankuasa Syariah di peringkat 
dalaman SPT masing-masing. Ini bererti parameter penerimaan risiko antara satu SPT dengan SPT yang mungkin berbeza. Selanjutnya merupakan potensi risiko syariah berkaitan system SPT.

Rajah 5: Potensi Keterdedahan Risiko Syariah Berkaitan Sistem

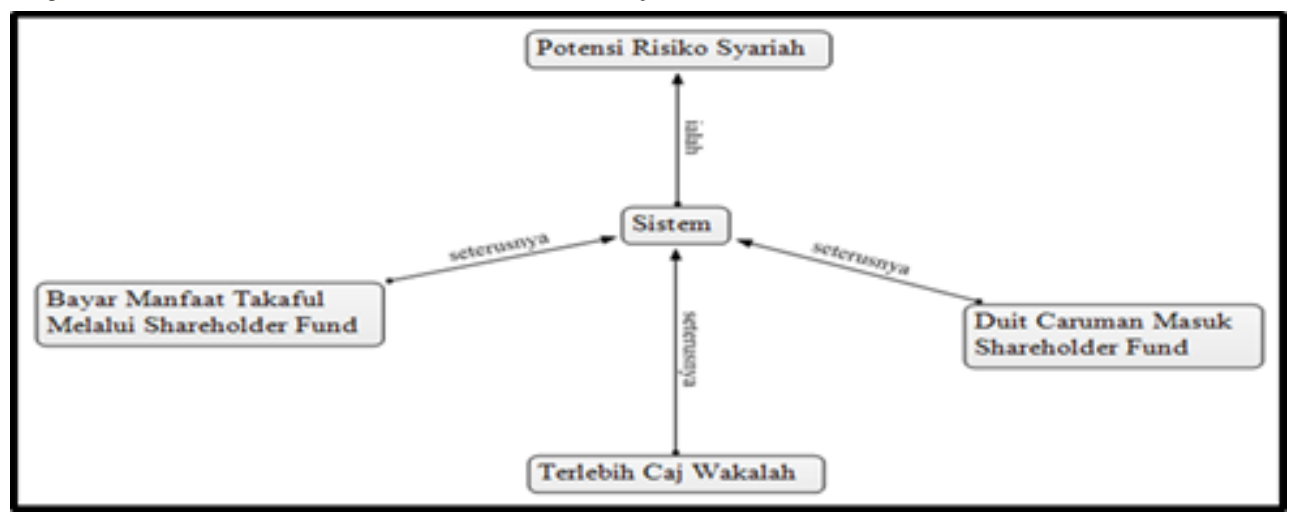

Potensi keterdedahan risiko syariah juga boleh berlaku disebabkan oleh sistem dalam SPT. Hal ini disebabkan sistem tersebut tidak menguruskan dana-dana berdasarkan kontrak takaful. Ini berikutan kebanyakkan sistem SPT dibangunkan untuk keperluan syarikat insurans konvensional. Potensi keterdedahan risiko syariah melibatkan sistem contohnya apabila terdapat sistem yang mengagihkan dana-dana caruman yang diterima terus kepada dana pemegang saham tanpa mengagihkan kepada dana risiko peserta sepertimana yang sepatutnya berdasarkan model operasi kontrak takaful. Begitu juga contohnya apabila terdapat keperluan untuk membayar tuntutan manfaat takaful daripada para peserta. Sistem yang telah dibina telah mengambil dana pembayaran terus daripada dana pemegang saham. Sedangkan dalam praktis model takaful, pembayaran manfaat takaful perlu diambil daripada dana risiko perserta takaful tersebut. Pegawai Bahagian Syariah SPT E menyatakan apabila proses penilaian semula syariah dijalankan mendapati duit caruman yang dibayar oleh peserta masuk terus ke dana pemegang saham. Setelah beberapa tempoh masa barulah wang caruman para peserta diagihkan mengikut dana risiko peserta, dana pelaburan dan dana pemegang saham sepertimana yang dipersetujui dalam kontrak takaful. Walau bagaimanapun, bahagian syariah SPT E telah memperolehi penjelasan memuaskan daripada bahagian kewangan mengenai isu ini termasuklah melibatkan jumlah sebenar caruman dan keuntungan yang diperolehi semasa wang caruman tersebut disimpan dalam dana pemegang saham. Isu ini turut dibentangkan kepada Jawatankuasa Syariah SPT E dan hasil perbincangan Jawatankuasa Syariah membuat keputusan bahawa isu dana caruman para peserta terus kepada dana pemegang saham bukan merupakan insiden risiko syariah tetapi melibatkan sistem kewangan yang memerlukan tempoh masa yang lebih untuk mengagihkan dana-dana caruman para peserta takaful. Tambahan lagi, bahagian kewangan SPT E sendiri telah membuat insiatif untuk membangunkan sistem yang mampu mengagihkan dana-dana caruman peserta sepertimana yang dipersetujui dalam kontrak takaful sekaligus menunjukkan usaha semua kakitangan SPT bagi menambahbaik pematuhan syariah dalam SPT tersebut.

Pegawai Syariah SPT E juga mengulas mengenai sistem pembayaran tuntutan manfaat takaful daripada dana pemegang saham SPT. Namun begitu, beliau berpendapat pembayaran manfaat takaful tidak mempunyai sebarang isu tidak patuh syariah. Ini kerana tujuan pembayaran manfaat takaful daripada dana pemegang saham kerana dana tabarru' takaful perlu mengambil tempoh masa tertentu untuk dicairkan bagi pembayaran manfaat takaful tersebut. Dana tabarru' takaful biasanya akan dilaburkan dalam portfolio pelaburan jangka panjang seperti sukuk. Oleh yang demikian, dana pemegang saham akan membayar terlebih dahulu kepada peserta takaful tersebut dan seterusnya akan dituntut semula bayaran tersebut daripada dana tabarru' takaful.

Pegawai Syariah SPT D pula mengatakan potensi keterdedahan risiko syariah boleh berlaku akibat kegagalan sistem dalam operasi SPT. Contohnya, terdapat insiden risiko syariah telah berlaku 
apabila sistem telah mengenakan kadar caj wakalah yang lebih tinggi berbanding jumlah yang sepatutnya. Isu ini telah dibentangkan kepada Jawatankuasa Syariah SPT D dan telah memutuskan bahawa kegagalan sistem yang menyebabkan caj wakalah berlebihan merupakan insiden risiko syariah. Pegawai Syariah SPT D mengambil tindakan melaporkan insiden tersebut kepada BNM dan menjalankan tindakan selanjutnya, termasuklah mengasing dan mendermakan sejumlah dana yang telah diputuskan Jawatankuasa Syariah yang dianggap sebagai pendapatan tidak diiktiraf syariah kepada pihak-pihak yang bersesuaian. Selain itu, terdapat juga satu kes potensi risiko syariah berkaitan produk takaful.

Dalam produk takaful, tidak terdapat banyak potensi keterdedahan risiko syariah berkaitan produk-produk takaful yang ditawarkan oleh SPT. Walau bagaimanapun, terdapat satu kes potensi risiko syariah yang melibatkan produk pembayaran manfaat takaful secara tunai dan berjadual dengan terma serta syarat tertentu seperti yang ditunjukkan. Produk ini juga dikenali 'cash out payment product'. Pegawai Syariah SPT A dan Pegawai Syariah SPT B menyatakan bahawa produk ini telah diperakui di peringkat Majlis Penasihat Syariah BNM dan Jawatankuasa Syariah SPT masing-masing sebagai patuh syariah. Namun begitu, masih terdapat pertikaian daripada individuindividu berkepakaran syariah yang mengatakan bahawa produk cash out payment product ini menyerupai kontrak riba. Begitu juga Pegawai Syariah SPT E turut mempunyai pandangan berbeza mengatakan cash out payment product yang dipraktiskan oleh kebanyakkan SPT mempunyai banyak kekeliruan dan tidak mencapai tahap status patuh syariah yang memuaskan. Oleh yang demikian, bahagian pembangunan produk SPT E telah membentuk produk cash out payment yang baru tetapi menggunakan model yang berlainan yang lebih diyakini mengenai status patuh syariah produk tersebut. Pertikaian dan perbezaan pendapat mengenai status patuh syariah ini menyebabkan berpotensi untuk terjadi insiden risiko syariah dalam SPT. Walau bagaimanapun, isu berkaitan produk cash out payment bukanlah merupakan insiden risiko syariah berikutan telah diputuskan mengikut resolusi syariah di peringkat Jawatankuasa Syariah dalaman SPT sebagai produk patuh syariah. Sekiranya produk cash out payment diperakui patuh syariah oleh Jawatankuasa Syariah SPT, maka pihak SPT tersebut boleh memasarkan produk cash out payment ini sebagai patuh syariah.

Selain daripada potensi keterdedahan risiko yang telah dijelaskan di atas, terdapat pelbagai potensi risiko syariah dalam SPT telah diringkas sepertimana rajah 8 berikut:

Rajah 8: Potensi Risiko Syariah dalam SPT

\begin{tabular}{|l|c|c|c|c|c|}
\hline Potensi Keterdedahan Risiko Syariah & $\begin{array}{l}\text { SPT } \\
\text { A }\end{array}$ & $\begin{array}{l}\text { SPT } \\
\text { B }\end{array}$ & $\begin{array}{l}\text { SPT } \\
\text { C }\end{array}$ & $\begin{array}{l}\text { SPT } \\
\text { D }\end{array}$ & $\begin{array}{l}\text { SPT } \\
\text { E }\end{array}$ \\
\hline Akad tuntutan pihak ketiga terhadap manfaat takaful & 0 & 0 & 0 & $/$ & 0 \\
\hline Bayar Manfaat Takaful Melalui Dana Pemegang Saham & 0 & 0 & 0 & 0 & $/$ \\
\hline Duit Caruman Masuk ke Dana Pemegang Saham & 0 & 0 & 0 & 0 & $/$ \\
\hline Kegagalan Membayar Tuntutan & 0 & $/$ & 0 & 0 & 0 \\
\hline Kelemahan Jawatankuasa Syariah & $/$ & 0 & 0 & 0 & 0 \\
\hline Kelemahan Pegawai Syariah Dalaman & 0 & 0 & $/$ & 0 & 0 \\
\hline Kesilapan dalam penyataan brosur & 0 & 0 & 0 & 0 & $/$ \\
\hline Kesilapan Istilah dan Teknikal & 0 & 0 & $/$ & 0 & 0 \\
\hline $\begin{array}{l}\text { Ketiadaan Parameter dalam Penerimaan Risiko dalam } \\
\text { Takaful Am }\end{array}$ & $/$ & 0 & 0 & 0 & 0 \\
\hline Ketiadaan Penyataan Caj Wakalah & 0 & 0 & 0 & $/$ & 0 \\
\hline
\end{tabular}




\begin{tabular}{|l|c|c|c|c|c|}
\hline Ketiadaan Sokongan CEO & 0 & 0 & 0 & $/$ & 0 \\
\hline $\begin{array}{l}\text { Penerima Risiko Takaful Am dan Keluarga } \\
\text { Berkumpulan Bagi Syarikat Bercampur }\end{array}$ & 0 & $/$ & $/$ & $/$ & $/$ \\
\hline Penerimaan Risiko Takaful Keluarga Individu & 0 & 0 & $/$ & $/$ & 0 \\
\hline Percampuran Transaksi Takaful Am dan Keluarga & $/$ & 0 & 0 & 0 & 0 \\
\hline Pertikaian Metod Zakat & 0 & 0 & 0 & 0 & $/$ \\
\hline Pertikaian terhadap Hibah Bersyarat & $/$ & 0 & 0 & 0 & 0 \\
\hline Produk berkaitan "Cash Out Payment" & $/$ & $/$ & 0 & 0 & $/$ \\
\hline Risiko Syariah dalam Pelaburan & $/$ & $/$ & 0 & $/$ & $/$ \\
\hline Terlebih Caj Wakalah & 0 & 0 & 0 & $/$ & 0 \\
\hline Tiada Kepakaran Audit Syariah & $/$ & 0 & 0 & 0 & $/$ \\
\hline Tiada Ketelusan Maklumat & 0 & 0 & $/$ & 0 & 0 \\
\hline Tiada Sokongan Kakitangan Berkaitan & 0 & 0 & 0 & $/$ & 0 \\
\hline Transaksi kontrak segera & 0 & 0 & $/$ & 0 & 0 \\
\hline
\end{tabular}

Rajah 8 menunjukkan potensi risiko syariah dalam operasi sebenar SPT hasil temubual lima informan daripada lima SPT yang berlainan. Simbol "/" dalam Rajah 8 menunjukkan terdapat potensi isu syariah yang dinyatakan oleh Pegawai Syariah SPT yang ditemubual. Manakala "0" pula menunjukkan tiada potensi isu syariah yang dinyatakan oleh Pegawai Syariah SPT yang telah ditemubual. Kajian ini menggunakan proksi SPT A, SPT B, SPT C, SPT D dan SPT E bagi mewakili Pegawai Syariah SPT yang telah ditemubual dalam kajian ini. Rajah 8 turut menunjukkan kebanyakkan SPT berhadapan dengan potensi risiko syariah dalam menerima risiko daripada syarikat-syarikat bercampur. Syarikat bercampur dalam konteks kajian ini bermaksud syarikat yang menjalankan perusahaan dan transaksi bercampur antara transaksi patuh syariah dan tidak patuh syariah. Syarikat bercampur ini memohon untuk menyertai kontrak takaful am ataupun takaful keluarga untuk melindungi kakitangan syarikat yang dibiayai oleh syarikat bercampur tersebut. Kesemua SPT membuat keputusan untuk menerima atau menolak permohonan kontrak takaful daripada syarikat-syarikat bercampur adalah berdasarkan keputusan Jawatankuasa Syariah SPT masing-masing. Terdapat indikator tertentu yang digunakan oleh SPT untuk menentukan penerimaan dan penolakkan permohonan takaful contohnya berdasarkan penyata kewangan syarikat bercampur tersebut dengan metodologi penyaringan status patuh syariah yang dikeluarkan oleh Suruhanjaya Sekuriti Malaysia. Namun begitu, terdapat SPT yang lebih terbuka menerima permohonan syarikat bercampur dengan melihat status perusahaan utama dan majoriti aktiviti perniagaan syarikat tersebut sama ada melihatkan perniagaan halal atau yang jelas bertentangan dengan syariah seperti arak, perjudian, dan riba. Sekiranya syarikat bercampur dilihat menjalankan perusahaan utama yang halal serta mempunyai usaha dan komitment yang tinggi dalam meningkat jumlah transaksi patuh syariah. Terdapat SPT yang menerima permohonan takaful syarikat takaful tersebut dengan justifikasijustifikasi tertentu setelah mendapat pengesahan daripada Jawatankuasa Syariah SPT. Dengan erti kata yang lain, penerimaan risiko daripada perspektif patuh syariah antara satu SPT dengan SPT yang lain mungkin berbeza antara satu sama lain. Ini bermaksud sekiranya permohonan syarikat bercampur ditolak oleh SPT tertentu, akan tetapi permohonan syarikat bercampur tersebut mungkin diterima di SPT yang lain disebabkan perbezaan interpretasi dan ijtihad Jawatankuasa Syariah antara satu SPT dengan SPT yang lain. 
Selain itu, majoriti Pegawai Syariah SPT yang telah ditemubual menyatakan terdapat potensi risiko syariah dalam pelaburan melibatkan pemilihan kaunter-kaunter saham patuh syariah untuk melaburkan dana-dana takaful. Bahagian pelaburan SPT sama ada di peringkat dalaman SPT atau pihak luaran yang dilantik untuk menguruskan pelaburan SPT perlu memastikan dana-dana takaful dilaburkan dalam kaunter-kaunter pelaburan yang patuh syariah. Bahagian pelaburan SPT secara berkala perlu melaporkan status patuh syariah dana-dana takaful yang telah dilaburkan kepada Jawatankuasa Syariah SPT sebagai langkah pemantauan untuk menguruskan risiko syariah dalam pelaburan dana-dana takaful. Pegawai Syariah SPT A, B, D dan E turut menjelaskan dana-dana pelaburan syariah perlu dipantau dengan teliti terutamanya apabila terdapat senarai baru kaunterkaunter patuh syariah yang dikeluarkan oleh Suruhanjaya Sekuriti pada Mei dan November setiap tahun. Ini berikutan kemungkinan terdapat kaunter-kaunter sebelum ini adalah patuh syariah tetapi telah dikeluarkan daripada senarai status patuh syariah apabila senarai patuh syariah baru dikeluarkan. Sekiranya terdapat kaunter-kaunter pelaburan yang telah dinyahsenarai daripada senarai patuh syariah, bahagian pelaburan SPT perlu melakukan pelan tindakan tertentu berdasarkan garis panduan yang telah dikeluarkan oleh Suruhanjaya Sekuriti (2015).

Namun begitu, kesemua potensi keterdedahan risiko syariah ini dinyatakan bukan merupakan insiden risiko syariah kecuali satu kes sahaja yang melibatkan terlebih caj wakalah yang dikategorikan sebagai insiden risiko syariah. Potensi risiko syariah yang lain bukan merupakan insiden risiko syariah. Walau bagaimanapun, potensi risiko syariah ini perlu diuruskan dengan pendekatan pengurusan risiko syariah bagi mengelakkan dan mengurangkan impak risiko syariah dalam industri takaful. Seksyen 28 (3) Akta Perkhidmatan Kewangan Islam 2013 turut memperuntukkan semua institusi kewangan Islam termasuklah industri takaful untuk menguruskan sebarang ketidakpatuhan di peringkat dalaman institusi. Malahan, rangka kerja tadbir urus syariah turut mengemukakan garis panduan umum pengurusan risiko syariah melalui pemahaman dan pengenalpastian risiko syariah, pengukuran risiko syariah, pemantauan risiko syariah, dan pengawalan risiko syariah. Namun demikian, rangka kerja ini hanya memberi gambaran awal sahaja mengenai pengurusan risiko syariah dan mencadangkan institusi kewangan Islam membangunkan proses pengurusan risiko secara komprehensif di peringkat institusi kewangan Islam tersebut. Kajian ini hanya terhad dalam menjelaskan mengenai elemen-elemen utama risiko syariah, teoritikal potensi risiko syariah, dan mengenalpasti potensi risiko syariah dalam SPT terpilih di Malaysia dan mencadangkan kajian lanjut mengenai proses pengurusan risiko syariah di institusi kewangan Islam sama ada secara kualitatif ataupun kuantitatif.

\subsection{KESIMPULAN}

Dapatan kajian menunjukkan kelima-lima SPT ini mempunyai potensi risiko syariah dalam operasi dan aktiviti SPT. Potensi risiko syariah dalam operasi SPT juga dilihat sering berbeza dan sukar dijangka antara satu SPT dengan SPT yang lain. Walau bagaimanapun, kebanyakkan potensi risiko syariah telah diuruskan di peringkat dalaman SPT apabila Jawatankuasa Syariah memutuskan bahawa potensi keterdedahan risiko syariah tersebut tidak dianggap insiden tidak patuh syariah atau sebaliknya dengan justifikasi-justifikasi yang dikeluarkan melalui resolusi Jawatankuasa Syariah SPT masing-masing. Ini selaras dengan peruntukkan perundangan seksyen 28(4) Akta Perkhidmatan Kewangan Islam 2013 yang memberi tanggungjawab menguruskan insiden risiko syariah di peringkat institusi kewangan Islam masing-masing. Hanya terdapat satu kes potensi keterdedahan risiko syariah diputuskan sebagai insiden risiko syariah. Namun demikian, kajian ini menyimpulkan bahawa insiden risiko yang dilaporkan kepada BNM tidak memberi imej negatif kepada SPT bahkan 
menunjukkan insiatif dan komitmen yang tinggi SPT dalam memenuhi liabiliti para peserta dan memastikan pematuhan syariah dalam operasi takaful.

\section{Rujukan}

Ahmad Hidayat Buang. (2000). Studies in the Islamic Law of Contracts: The Probihition of Gharar. Kuala Lumpur: International Law Book Services.

Ahmad Ibrahim Biq. (1936). The Shari'ah Financial Transaction. Cairo: Dar Al-Ansar.

Akta Bank Negara Malaysia 2009 (Akta 701).

al-Khafif, Syeikh ‘Ali. (1996). Ahkam al-Mu’amalat al-Syari yyah. Cairo: Dar al-Fikr al-Arabi.

Archer, S. \& Haron, A. (2007). Operational Risk Exposures of Islamic Banks, In Islamic Finance: The Regulatory Challenge, ed. Archer, S. \& Abdel Karim, R. Singapore: John Wiley \& Sons.

Asyraf Wajdi Dusuki, Mohammad Mahbubi Ali \& Lokmanulhakim Hussain. (2012). A Framework for Islamic Financial Institutions to Deal with Shari'ah Non-Compliant Transactions. ISRA Research Paper 42: 27-32.

Bailey, C. A. (2007). A Guide to Qualitative Field Research. (2 ${ }^{\text {nd }}$ ed). United Kingdom: Sage Publication Ltd.

Bälz, K. (2008). Shari'ah risk? How Islamic Finance has Transformed Islamic Contract Law. Occasional Publications 9, Islamic Legal Studies Program. Cambridge, MA, Harvard Law School.

Bank Negara Malaysia. (2011). Shariah Governance Framework for Islamic Financial Institutions. Kuala Lumpur: Bank Negara Malaysia.

Bank Negara Malaysia. (2015). List of Takaful Operator in Malaysia. Retrieved From Bank Negara Malaysia. Dicapai daripada website: http://www.bnm.gov.my/index.php?ch=li\&cat=insurance \&type=TKFF\&fund $=0 \& c u=0$,

DeLorenzo, Shaykh Yusuf Talal. (2007). Shari'ah Compliance Risk. Chicago Journal of International Law 7: 397- 408.

Denzin, N. \& Lincoln, Y. (2005). Paradigm and Perspectives in Transition, In The Landscape of Qualitative Research: Theories and Issues, ed. Denzin, N. \& Lincoln, Y., Ed. Ke-2. Thousand Oaks, CA; Sage Publication: 245-252.

Frenz, T., \& Soulhi, Y. (2010). Takaful \& Retakaful: Advanced Principles and Practices. $2^{\text {nd }}$ ed. Kuala Lumpur: IBFIM and Munich RE.

Ginena, K. (2014). Shari'ah Risk and Corporate Governance of Islamic Banks. Corporate Governance 14(1): 86-103.

Guba. E., \& Lincoln. Y. (1994). Competing Paradigma in Qualitative Research, In Handbook of Qualitative Research, ed. Denzin. L, \& Lincoln, Y. Thousand Oak, CA: Sage Publication.

Haron, A., \& Taylor, D. (2009). "Risk Management in Takaful, In Takaful Islamic Insurance: Concept and Regulatory Issues, ed. Archer, S., Abdel Karim, R. A., \& Nienhaus, V. Singapore: John Wiley \& Sons, 2009.

Hussin Salamon. (2009). Perkembangan Pasaran Modal Islam Dalam Pembangunan Ekonomi Negara, Jurnal Teknologi 50(9): 1-10. 
Ibn Dawiyan, Ibrahim Ibn Muhammad. (1972). Manar Al-Sabil Fi Sharh Al-Dalil. Dimashq: al-Maktab al-Islami.

Ibn Rushd. (1995). Bidayatul Mujtahid Wanihawat al-Muqtasid. (4rd ed). Cairo: Dar As-Salam.

Islamic Financial Services Board. (2009). Explosure Draf 14: Standard on Risk Management for Takaful (Islamic Insurance) Undertaking.

Jawatankuasa Fatwa Kebangsaan. (1984). Laporan Badan Petugas Penubuhan Syarikat Insurans Secara Islam di Malaysia.

Lahsasna, A. (2014). Shari'ah Non-Compliance Risk Management And Legal Documentations In Islamic Finance. Kuala Lumpur: Wiley Finance Series.

MIDF Islamic Finance. (2013). Shariah Compliance Function. Retrieved From laman sesawang MIDF Islamic Finance website dicapai: http://www.midf.com.my/profile/shariah-governance-control/shariahcompliance-function

Mohd Faiz Mohamed Yusof et al. (2015). Tadbir Urus Syariah dalam Industri Takaful di Malaysia: Implikasi Pra dan Pasca Akta Perkhidmatan Kewangan Islam 2013. Sains Humanika 5(1): 77-85.

Mohd Ma'sum Billah. (2003). Islamic Insurance (Takaful). Petaling Jaya: Ilmiah Publisher Sdn Bhd.

Muhammad Solah al-Sowi. (1990). Musykilah al-Istithmar fi al-Bunuk al-Islamiyyah. Kaherah: Dar alWafa: Kaherah.

Muslehuddin, M. (1979). Insurance and Islamic Law. $3^{\text {rd }}$ ed. Lahore: Islamic Publication Ltd.

Muslim, Ibn al-Hajjaj Abu al-Husayn al-Qusyayri al-Naysaburi. (1955). Musnad Sohih Al-Muqhtasor Binaqlu Al-Adl Ayn Al-Adl Ila Rasulullah S.A.W (Sahih Muslim). Jil ke-3. Beirut: Dar al-Nasyar; Darul Ihya’ al-Turath al-`Arabi. Ditahqiq oleh Muhammad Fuad`Abdul al-Baqi.

Muslim, Ibn Hajjaj al-Qusayri. (1981). Shahih Muslim bi Sahrh al-Nawawi. Jil ke-11. Mesir: AlMatba'ah al-Misriyyah wa Makatabuha.

Rusni Hassan et al. (2013). Survey on Implementation of Internal Shariah Compliance Function in Malaysian Islamic Banks and Takaful Companies, In Recent Advances in Management, Marketing and Finances: 7th WSEAS International Conference on Management, Marketing and Finances (MMF '13) Volume 4 of Business and economics series. Cambridge: Wseas LLC.

Saldana, J. (2013). The Coding Manual for Qualitative Research. $2^{\text {nd }}$ ed. London: Sage.

Suruhanjaya Sekuriti. (2015). Sekuriti Sekuriti Patuh Syariah oleh Majlis Penasihat Syariah Suruhanjaya Sekuriti Malaysia 27, 28 November 2015. Suruhan Sekuriti Malaysia.

Zulkifli Hasan. (2012). Shari'ah Governance in Islamic Banks. Edinburgh University Press: Edinburgh. 